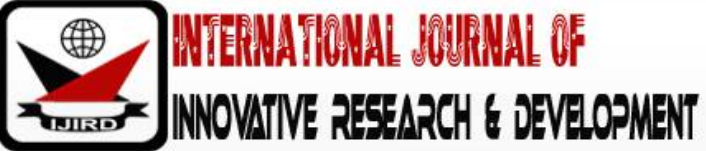

ISSN 2278-0211 (Online)

\section{A Systematic Review of the Challenges of Local Government Administration in the Development of Rural Communities in Ezza-North LGA, Ebonyi State, Nigeria}

\author{
Dr. Iyiani Christian Chidozie \\ Senior Lecturer, Department of Social Work, University of Nigeria, Nsukka, Nigeria \\ Aghedo Gabriel Usiagu \\ Lecturer, Department of Social Work, University of Nigeria, Nsukka, Nigeria \\ Okah Paulinus Sunday \\ Lecturer, Department of Social Work, University of Nigeria, Nsukka, Nigeria
}

\begin{abstract}
:
Local government system in Nigeria was established and empowered to engender socio-economic development in the rural areas. However, despite the constitutional backing and resources accruing to it, local government has not performed much in terms of rural development as many rural communities still lack amenities and infrastructure needed for quality living. This study reviewed the challenges of local governments' administration in the development of rural communities in Ezza-North LGA, Ebonyi State. Documentary analysis was employed in the review of the concept, evolution, and challenges of local governments as well as social work implications of the study. The study revealed that lack of fund, corruption, lack of autonomy etc.were the major challenges of local governments in Nigeria. The study recommended that full autonomy should be granted to local governments to enable them perform better. Social workers should work as a link between the government and the rural populace for effective service delivery.
\end{abstract}

Keywords: Administration, challenges, development, local government, review, rural communities

\section{Introduction}

In the contemporary world, the need to transfer administrative power and authority from the centre to the peripheries or grassroots level for effective representation and good governance has become popular in both the developed and developing countries (Lawal, 2014). This is because most people live in the rural areas where social amenities are almost not available. According to Oyedele, Osezua, Abdulkareem, \& Ishola (2017), over 70\% of Nigerians live in the rural areas where there is an inadequacy of social amenities and infrastructures needed for good living and meeting other economic needs. Udoh (2005) further states that more than 100 million Nigerians especially those in rural areas do not have access to electricity, with less than $40 \%$ of Nigerian populace having access to safe drinking water. This is because infrastructures are mostly executed in urban areas with little or no attention to social amenities in the rural areas.

As a result of the disparities between the rural and urban areas in terms of infrastructure, social amenities, human development, and the overall general standard of living, there has been increasing concern and agitation for the development of the rural areas through decentralization of power and functions to the local government system (Ogbazi, 1982; Ogbette, Idam \& Kareem, 2018). Therefore, there is the need for the provision of social amenities like water, electricity, healthcare, access roads, and quality education to the infrastructural disadvantaged and poor rural dwellers in Nigeria. Adebayo (2014) equally opined that local government was created to ensure effective and efficient service delivery to the people at the rural areas as development would only be said to have taken place when the rural people benefit. Therefore, to ensure that developments get to the rural areas, local government system was created.

The need for the creation of local government stems from the fact that the rural areas require infrastructural development (Tiku, Obeten, \& Onyenemerem, 2019). As the closest government to the people, it is the responsibilities of the local government to provide for the local populace, take care of their needs and develop their areas (Fajonyomi \& OluOwolabi, 2013). According to Oyedele, Osezua, Abdulkareem, \& Ishola (2017), the responsibilities of providing the local population with social and economic services needed for survival, quality living and political participation fall within local government administration. The creation of local government in Nigeria was borne out of the need to engender aggressive infrastructural development and quality service delivery in the rural areas (Sehinde, 2008). Local governments are therefore constitutionally empowered to construct and maintain rural roads, street lighting, water and drains, and other highways or such public facilities (Federal Government of Nigeria [FGN], 1999). 
Like many other countries that practice federalism, Nigerian government is constitutionally divided into federal, state and local governments. As the closest government to the grassroots, local government is adjudged the best institutions for encouraging and mobilizing the rural people for self-help projects and participation in the decision-making process of the local authority (Ibietan, 2010). Despite these provisions, the rural people still lack access to basic amenities such as safe water, electricity, good roads, education, unemployment, and healthcare (Lawal, 2014). Adebayo (2014) observed this when he states that in spite of the relevance of local government system, there are some problems affecting its efficiency especially in areas of service delivery at the grassroots. This is because water supply is neither safe nor adequate for their needs, local roads are impassable, electricity supply where it exists is epileptic, and health centres are dilapidated. In view of the above, Sehinde (2008) and Ayee (2003) state that since its creation, the contribution of local government in the development of rural areas have been very low owing to the amount of resources accruing to it, thereby casting doubts in the minds of the people on the effectiveness and importance of local governments. According to Lawal (2014), there is a general impression by the people that local governments are very weak in terms of massive infrastructure geared towards rural development. In other words, the rural people still lack amenities needed for wellbeing and healthy living.

Ezza-North LGA has over the years initiated and completed various community development projects across the 14 autonomous communities in the area. Some of such projects include bridges, health centres, culverts, adult education centres, electricity, feeder roads, boreholes, filling of potholes, construction of drainages, and establishment and equipment of security outfits. Just recently, the council gave 4 million naira to each of the 14 communities as take-off grants to embark on projects of their choice; and upgraded and equipped the council's general hospital at Umuezeoka community. Despite these achievements, Ezza-North has failed to adequately provide the rural communities with amenities and infrastructures needed for good and quality living, as many villages are yet to feel the socio-economic impacts of the council. According to Ndukwe and Nwokwu (2018), notwithstanding all these measures and feats by the council, poverty, unemployment, and illiteracy levels are still high among the rural dwellers in Ezza-North; with many people dying of preventable diseases. In addition, agriculture, which is known as the major occupation of the people is being relegated as many people particularly youth now move in their numbers to cities because of lack of social amenities and infrastructures needed for quality living in the area.

\section{The Concept of Local Government}

It is argued that no government can foster effective administration by giving orders and instructions only from the centre without devolving activities, power and functions to the lower levels of government, like local government (Olukotun, 2007). Therefore, there is the need for a government that can easily reach the people at the grassroots, thus, the imperativeness of local government system. Local government in the communal sense means peoples' political instrument to participate in resource allocation, distribution and acquisition (Ibietan, 2010). Akpan (2001) described local government as the splitting of the administration of the country and transferring some power and functions to the local units, with elected representatives as local authority who though are answerable to the central or higher authority are responsible for effective service delivery and development of the rural areas. In the views of Fajobi (2010), local government is the transfer or delegation of political power and authority from the state to the grassroots. It is defined as an authority within the local communities for the purpose of maintaining law and order, provision of social amenities, and improving the living conditions of the rural populace through cooperation and participation in governance (Igwugwum, 2013).

The 1976 Nigerian local government reform guidelines defined local government as government at the grassroots, established and empowered by law to function within a clearly defined area through representative council elected by the people. The law empowers the council to have control over local affairs, institutional and financial powers to initiate and direct the provision of services; determine and implement projects so as to compliment the activities of the state and federal governments in their areas; and to ensure through devolution of these functions to these councils through the active participation of the people and their traditional institutions to ensure that local initiative and response to local needs and conditions are maximized (FGN, 1976). In Nigeria, local government administration speaks of representative councils empowered with substantial control of local affairs to complement the activities of federal and state governments in the provision of goods and services and implementation of projects aimed at socio-economic development of rural areas (Tiku, Obeten, \& Onyenemerem, 2019). This is because the activities of government at the local level are very crucial in the provision of goods and services to the people as well as overall rural development of the grassroots (Ibok, 2014).

\section{Evolution of Local Government in Nigeria}

Local government in Nigeria is not a new phenomenon because it predated colonial era of British administration. According to Adeyemi (2019), it had been part of system of government among ethnic groups in Nigeria especially the Yoruba, Hausa/Fulani, and Igbo, in the West, North and East respectively. The history of local government in Nigeria is a blend of tradition and modernity ushered in by periods of trial and error (Fatile, Majekodunmi, \& Adejuwon, 2013). In precolonial times, it revolved around the traditional authority of each locality and was acknowledged and respected (Ola, 2004). Since then, the local government has passed through native authority system (indirect rule) to divisional, district and council manager-ship, as well as a system of local government that was introduced by the 1976 reform thereby making local government system in Nigeria a uniformed administrative structure (Adeyemi, 2019). This reform according to Bello (2007) recognized the local government as a district tier of government. Over the years local government has passed through changes in name, composition and structure as it was known as chief-in-council, and chief-and-council, between 1930s and 1940s with traditional rulers given pride of place in the scheme of things (Arowolo, 2010). 
In 1950s, election was introduced in line with the British system in the Western and Eastern parts of the country with some measures of autonomy in personnel, finance and general administration (Nwabueze, 1982). Owing to this development, there was an increasing progress in growth and development in these areas and this development were more noticeable in the South than in the North. In addition, there was no uniformity in the system and no equality in the level of development within this period as heterogeneity was the basis of local authority (Lawal, 2014). However, the 1976 reforms of General Olusegun Obasanjo's administration brought about uniformity in the administrative nature of local governments throughout the country (Ajayi, 2000). Moreover, the system made provision for elective positions, with the chairman as the executive head of local government, and supervisory councilors as the cabinet and complimented by bureaucrats and professionals charged with the responsibility of implementing policies (Lawal, 2014). In 1991, General Ibrahim Babangida's administration introduced legislative arm in the local government, thereby constitutionally empowering the local governments to have elected councilors. Within this period, the number of local government areas in Nigeria was increased. According to Aikhomu (1993), in an attempt to bring government and development nearer to the grassroots and create political awareness, mobilization and participation, the Nigerian government increased the number of local governments from 449 in 1976 to 589 in 1991. The number was also increased to 774 local governments in 2001 (Olokotun, 2007), and was granted financial autonomy in 2020 by Muhammadu Buhari's administration.

\section{Theory of Decentralization}

Decentralization theory was first put forward by Alexis de Tocqueville in 1835, and popularized by Wallace Oates in 1972. The theory explains the transfer of authority and responsibility from the central government to subordinate like local government or the private sector (Roindinelli, 1981; Heywood, 1997; Bonal, n.d). This theory argues that decentralization of power and function from centre to periphery leads to improved levels of political participation, accountability, administrative and fiscal potency (Oates, 1972; Wiesnar-Duran, 1992; Inter-American Development Bank \{IDB\}, 1994; Shah, 1994; Weingast, 1995). Decentralization is a set of policy targeted at delegating functions, tasks, resources, or power from higher to lower levels of administration (Agrawal, 2001). This decentralization could be political, administrative or fiscal in nature. Decentralization increases responsiveness to local needs, through the provision of public goods and services, and social amenities as a result of the looseness of the rural people with the government (Ravell, 2016).

As top-down hierarchical and centralized system of government fizzles away, low-and-middle income countries begin to shift attention from central type of government to more decentralized system with the aim of transferring powers and functions to lower tiers of government so as to address the needs of the rural dwellers (Mbate, 2017). Bringing government closer to the people, through decentralization, it is believed that local government will be more effective and efficient in developing the rural areas, provide the rural people with needed infrastructures, improve their welfare and foster accountability and transparency (Smoke \& White, 2005; Smith \& Ravell, 2016). In Nigeria and other low-and-middle income countries, decentralization is seen as a means of providing social amenities and infrastructures to the rural people through empowering local governments adjudged closest to the people with powers and responsibilities of developing local areas. According to Lawal (2014), local governments in Nigeria is generally seen as important vehicles for engendering development and improved service delivery to the rural populace. Despite the importance of decentralization theory in developing the rural areas, it has been criticized of encouraging excessive bureaucracy in governance. In addition, powerful local people and state governments can always influence the council's decision since they do not have full autonomy. According to Miller (2002), powerful local people can hijack and influence both economic and political decisions of the local governments for self-interest motives against the provision of amenities and societal welfare.

\section{Challenges Faced by Local Governments in Developing Rural Communities}

Over the years, it has been canvassed for national development to take off from the grassroots, since the local government is seen as a vehicle for rural transformation and delivering of effective socio-economic services to the rural people (Otoghile \& Edigin, 2011; Idike, 2014). However, this development has led to wide gap to what is expected of the local government and what is actually happening in the local government in terms of provision of socio-economic amenities (Oyedele, Osezua, Abdulkareem, \& Ishola, 2017). The failure of local government in terms of service delivery to its citizens has made them lose faith and trust in local government administration as an institution aimed at improving their welfare in Nigeria (Zakari ya 'u, 2014; Ogbette, Idam \& Karrem, 2018). According to available literature, the following challenges are responsible for the failure of local governments in Nigeria.

\subsection{Interference/Lack of Autonomy}

The inability of the federal government to grant full autonomy to the local governments has posed serious threats to local government administration throughout the country, and affected the level of rural development. Many rural communities are grossly underdeveloped thereby raising questions on the capabilities of local governments in rural development. According to Ehiri (2010), the inability of the local governments to provide the needed and adequate social services such as education, healthcare services etc. to the rural people is as a result of lack of autonomy. There is also high degree of external influence or lack of true autonomy, as many state governors continue to interfere in the affairs of local governments (Eboh \& Diejomaoh, 2010; Adeyemi, 2013). The state governments, through Local Governments Service Commission (LGSC), and States and Local Government Joint Account Committee (JAC) have unhindered access to local governments' funds throughout the country. With these, states have monopoly and control of local government affairs thereby making local councils their appendages. State governments also withhold at will local government's funds and spend same so imprudently that the local governments are somewhat incapacitated to perform their statutory functions to 
the rural dwellers. Sometimes, the local government chairmen are unconstitutionally removed thereby cutting short their constitutional tenure (Asani et al, 2011). It is therefore believed that rural areas will be developed in terms of socioeconomic infrastructure only when the local governments have full power to take financial, political, and social decisions (Tiku, Obeten, \& Onyenemerem, 2019). In addition, local governments in Nigeria will only assume their rightful places when they are granted all round autonomy with Independent National Electoral Commission conducting elections in local governments instead of States Independent Electoral Commissions.

\subsection{Lack of Fund}

It is a known fact that the amount of cash flow to local governments is lesser than that of their federal/state counterparts. Again, the amount of money that goes into some local governments' pause as internally generated revenue is too meager to execute any meaningful project. Both federal and state governments have interfered in the operations of local governments such that in some Nigerian states, local governments are seen as a branch of the state government and unlawfully withhold their statutory revenue allocation from the federation account. In addition, poor financing, policy inconsistency, corruption, political and economic interference, lack of autonomy, poor staffing and lack of technical expertise etc. all affect the potency of local governments (Eboh \& Diejomaoh, 2010; Tolu \& Olagunjoye, 2010; Coker \& Adams, 2012; Adeyemi, 2013; Agba, Akwara, \& Idu, 2013; Ibok, 2014; Bolatito \& Ibrahim, 2014; Chukwuemeka, Ugwuanyi, Ndubuisi-Okolo, \& Onuoha, 2014). Finance is very crucial in the running of effective government because funds availability ensure good governance (Uchechukwu \& Obiora, 2016). Therefore, lack of fund has made it difficult for local governments to carry out to the fullest, the responsibilities of developing rural areas and improving the living conditions of the rural populace.

\subsection{Corruption}

Corruption has been identified as one of the biggest challenges facing the smooth running of local governments in Nigeria as many local government authorities indulge in massive fraud and diversion of funds meant for the development of rural areas thereby living the masses in penury, and the rural areas undeveloped. The fabrics of local government system in Nigeria has been eaten deep by massive corruption as wide-scale fraud, embezzlement, inflated and abandoned contracts etc. combine in various forms to affect the objectives and efficiency of the local governments (Bolatito and Ibrahim, 2014; Alao, Osakede, \& Owolabi, 2015; Odalonu, 2015).

\subsection{Misplaced Priority}

Another cog in the wheel of local government administration is misplacement of priority. Misapplication and misappropriation of fund is a big problem to local government administration in Nigeria. Many politicians or local governments' administrators often embark on white elephant projects because of the return they make from such projects. They care less about the welfare of the people and rather concern themselves with the benefits they make from carrying out the projects. Obasanjo (2003) posited that funds meant for development programmes at the rural areas are been mismanaged by servicing bloated elected officials and unproductive bureaucracies.

\subsection{Lack of Qualified Persons/Lack of Technical and Managerial Capacities and Skills}

Often, most qualified persons do not vie for electoral positions in the local governments; hence, unqualified individuals are elected to become councilors, supervisory councilors and chairmen of the councils (Odo, 2014). In collaborating the above, Ganduje (2008) observed that school drop outs are serving as chairmen and councilors in some local government councils in Nigeria. There is no doubt that these set of people can do little or nothing to ensure programmes and policies that will develop the rural areas; hence, the continuous deterioration of the grassroots.

\subsection{Lack of Participation and Involvement of the Rural People}

Exclusion of rural people in planning and execution of projects meant to benefit them has unarguably undermined the efforts of local governments in rural development. According to Odo (2014) and Kaka (2018), lack of involvement of the local people in the conception and implementation of projects has led to the failure of many rural development projects in the local governments because the problems of rural communities need to be solved through the cooperation of the community and the government. If people are involved in projects' planning and implementation, their views will be considered and they will see the projects as their own. According to Okah, Iyiani and Aghedo (2020), this will give them sense of belonging and spur them into participation, completion and judicious use of the projects.

\subsection{Lack of Accountability and Transparency}

Lack of Accountability and Transparency also affect good governance in the local areas.

\section{Implications to Social Work Practice}

Social work is an art, a science and a profession that helps people to solve their problems and attain satisfying personal, group and community relationships through social work practice (Farley, \& Smith, 2006). Social work education and profession have greater responsibility in the process of community development to ensure every member of the community enjoy safe, healthy and wealthy life (Dhavaleshwar, 2016). According to Beinstein (1995), social workers assist in restoring, maintaining, and enhancing the social functioning of individuals and the society through delivery of resources and services to meet the many and varied needs of the people. As professionals, social workers work towards development of projects and programmes designed to improve rural communities. In the course of doing this, social workers ensure 
collaboration of local government authority and the community people themselves in all the stages of the projects aimed at improving the living conditions of the people. In conjunction, they plan and execute programmes and projects meant to help the rural people better their lives. Social workers working to improve the conditions of the rural communities may be playing the role of caseworkers, community organizers, project managers, educators, enablers, councilors, or advocates etc.

The importance of social work practice in local government administration informed why education and social welfare department exists in every local government area in Nigeria, including Ezza-North. Social workers work with the local government authorities to improve the living standards of the rural dwellers. It is the duty of social workers at the local government level to recommend to the authority, projects needed in the rural areas, and work with both the local government authority and community members themselves to ensure projects conception, completion, utilization, and sustenance. Social workers at the grass root level also take charge of adult education programmes aimed at improving the literate level of the rural populace. They also educate the people on the need to always submit proposals to the government for community development projects as well as embark on self-help projects. Social workers can also stand for elective position such as chairmanship position in the local government area to help improve the rural communities. They champion pre and pro-poor policies that will be favourable to the poor and reduce poverty as well as encourage and empower them to take advantage of policies made to benefit and improve their lives (Okah, Iyiani, \& Aghedo, 2020). According to Sheafor and Herejsi (2006), social workers can facilitate linkage between individuals and available resources in the society. With the approval of the local government authority, social workers can link the rural people of Ezza-North with institutions that assist them in the provision of social amenities needed for survival, and source expertise from other professions to provide them with technical training and knowledge on business, agriculture and entrepreneurship (Okah, Iyiani, Esin \& Aghedo, 2020). They also recommend and link the indigent people especially widows to local government authority for assistance.

\section{Conclusion and Recommendations}

This study focused on the challenges of local government administration in rural communities of Ezza-North local government area of Ebonyi state. The study revealed that local government been the third tier of government, and closest to the people has not performed up to public expectations considering its statutory responsibilities and allocations accruing to it. Though Ezza-North has made some impacts on the living conditions of the rural populace through developmental projects and social amenities, its effective services has been affected by some factors including lack of fund, lack of autonomy, and mismanagement of fund; thereby leaving most of the communities in the area grossly underdeveloped with the masses suffering. In view of the above, the study made the following recommendations:

- The allocation sharing formula between the federal, states and local governments should be reviewed to allow more fund to local governments to enable them embark on, and execute more projects for the benefits of the infrastructural disadvantaged rural people.

- That the Ebonyi State House of Assembly should as a matter of urgency re-enact laws increasing the tenure of duly elected chairmen to 3 or 4 years. The present 2 years tenure for elected chairmen in Ebonyi state is too short for execution of any meaningful community development projects.

- Financial and political autonomy should be fully granted to the local governments in Nigeria to give them free and unhindered access to their fund and stop the state governors from withholding, amputating, and diverting the local government funds in the name of State and Local Government Joint Account.

- That only the qualified persons should be elected as chairmen and local government officials.

- There should be strict punishment for chairmen who are corrupt and arrogate to themselves the funds meant for rural development.

- The rural people themselves should be involved in planning and implementation of projects in their communities to ensure projects completion and sustainability.

- Local authorities should put in place youth empowerment and poverty reduction programmes to support the rural people.

- Security operatives should be inaugurated in the rural communities to assist in the protection and safeguarding of public properties.

- Social workers should be integral part of the conception and implementation of projects meant to benefit the rural populace. Already domiciled in every local government area, social workers must ensure that both the interest of the government and the people are protected. In addition, social workers should educate and encourage the people to embark on some projects on their own no matter how small they might be, rather than rely on government for everything.

\section{References}

i. Adebayo, A. S. (2014). Local government and the challenges of rural development in Nigeria (1999-2014). IOSR Journal of Humanities and Social Science, 19 (4), 21-32.

ii. Adeyemi, O. (2013). Local government and the challenges of service delivery: The Nigeria experience. Journal of Sustainable Development in Africa, 15 (7), 84-98.

iii. Adeyemi, O. O. (2019). Local government administration in Nigeria: A historical perspective. Journal of Public A dministration and Governance, 9 (2), 161-172.

iv. Agba, M. S., Akwara, A. F. \& Idu, A. Y. 2013. Local government and social service delivery in Nigeria: A content analysis. Academic Journal of Interdisciplinary Studies, 2 (2), 455-462. 
v. Agrawal, A. (2001). The decentralizing state: Nature and origins of changing environmental policies in Africa and Latin America (1980-2000). Paper read at annual meeting of the American Political Science Association, San Francisco, August 30 to September 2.

vi. Aikhomu A. A. (1993). Federal state relationship under military government (1985-1992). The Nigerian Journal of Federalism, 1 (1), 3-6.

vii. Ajayi, K. (2000). Theory and practice of local government. Ado Ekiti: University of Ado Ekiti Press Limited.

viii. Alao, D. O., Osakede, K. O., \& Owolabi, T. Y. (2015). Challenges of local government in Nigeria: Lessons from comparative analysis. International Journal of Development and Economic Sustainability, 3 (4), 61-79.

ix. Arowolo, D. (2010). Local government administration and the challenges of rural development in Nigeria. In A. Agagu, L. Afinotan, D. Arowolo, \& T. Lawal (Eds). Public Administration in Nigeria. Akure: Alabi-Eyo \& Co. Ltd.

x. Asani, M. A., Adie, D. B., Oke, L. A., Otun, J. A., Lukman, S., Odetola, A. A., Olatunji, S. A., \& Ajibike, M. A. (2011). Literature review on local government in Nigeria- Part A: Definitions and history of local government. Available at www.researchgate.net. \{Accessed 28 Sept., 2020\}.

xi. Ayee .J. (2003). Towards effective and accountable local government in Ghana. Accra: Ghana Centre for Democratic Development.

xii. Bello, I. B. (2007). The local government system in Nigeria. Ibadan, Nigeria: College Press and Publishers Ltd.

xiii. Bernstein, A. J. (1995). Redefining social work's emphasis on the 'social': The path to development. International Social Work, 38, 53-67.

xiv. Bolatito, S., \& Ibrahim, S. (2014). Challenges of local government administration in Nigeria: An appraisal of Nigerian experience. International Journal of Science and Research, 3 (7), 562-574.

xv. Bonal, J. (n.d). A history of decentration. Available at http://wwwcresin.org/decentralization/English/General /Historyfao.ht ml. \{Accessed 5 Aug., 2020\}.

xvi. Chukwuemeka, E., Ugwuanyi, B. I., Ndubuisi-Okolo, P. \& Onuoha, C. E. (2014). Nigeria local government: A discourse on the theoretical imperatives in a governmental system. An International Multidisciplinary Journal, 8 (2), 305-324.

xvii. Coker, M. A. \& Adams, J. A. (2012). Challenges of managing local government finance in Nigeria. Research on Humanities and Social Sciences, 2 (3), 1-12.

xviii. Dhavaleshwar, C. U. (2016). The role of social worker in community development. International Research Journal of Social Sciences, 5 (10), 61-63.

xix. Eboh, E. \& Diejomaoh, I. (2010). Local governments in Nigeria: Relevance and effectiveness in poverty reductin and economic development. Journal of Economic and Sustainable Development, 1 (1), 12-28.

xx. Ehiri, T. G. (2010). Comparative issues in local government administration. Ibadan: Baaj International Company.

xxi. Fajobi, O. F (2010). X-Ray of local government administration in Nigeria. Ibadan: Crest Hill Ltd.

xxii. Fajonyomi, O. S. \& Olu-Owolabi, F. E. (2013). Good governance and local government administration for development: Multiple perspectives. Journal of Capital Development in Behavioural Sciences, 1 (2), 1-15.

xxiii. Farley, O.W. \& Smith, L. L. (2006). Introduction to Social Work (10 th edition). Boston: Pearson.

xxiv. Fatile, J., Majekodunmi, A., Oni, A., \& Adejuwon, D. (2013). Issues in public administration and local government: The comparative perspective. Lagos: Concept Publication Limited.

xxv. Federal Republic of Nigeria (1999) Constitution of the Federal Republic of Nigeria. Lagos: Federal Government Press.

xxvi. Ganduje, A. U. (2008). Democracy and local government administration in Nigeria. Ibadan: Spectrum Books Ltd.

xxvii. Ibietan, J. (2010). The role of local government in rural development issues. Knowledge Review, 2 (2), 30-38.

xxviii. Ibok, E. E. (2014). Local governance and service delivery in Nigeria. Caribbean Journal of Science and Technology, 2, 536-541.

xxix. Idike, A. N. (2014). Local government and sustainable national development in Nigeria. European Scientific Journal, 10 (25), 161-170.

xxx. Igwugwum, C. W. (2013). Trace the evolution of local government in Nigeria from 1979 to 1999 and how important is it to the present-day local government. Available at chrisdonasco.blogspot.com. \{Accessed 30 Sept. 2020\}.

xxxi. Inter-American Development Bank (1994). Economic and social progress in Latin America: 1994 Report. Washington, DC: Johns Hopkins University Press.

xxxii. Kaka, E. B. (2018). Decentralization of local government and rural development in Rivers State, Nigeria. Available at https://scholarworks.waldenu.edu/dissertations. \{Accessed 2 Oct., 2020\}.

xxxiii. Lawal, T. (2014). Local government and rural infrastructural delivery in Nigeria. International Journal of Academic Research in business and Social Sciences, 4 (4), 139-147.

xxxiv. Mbate, M. (2017). Decentralization, governance and accountability: Theory and evidence. Journal of African Democracy and development, 1 (2), 1-16.

xxxv. Miller, K. (2002). Decentralization, local governance and community participation: A Caribbean perspective. Unpublished, Kingston, Jamaica.

xxxvi. Ndukwe, C., \& Nwokwu, P. M. (2018). Rethinking best strategies towards developing local government areas: Ezza-North LGA of Ebonyi State in focus. International Digital Organization for Scientific Research Journal of Arts and Management, 3 (1), 74-87.

xxxvii. Nwabueze, B.O. (1982). A constitutional history of Nigeria. London: Longman Press Limited.

xxxviii. Oates, W. (1972). Fiscal federalism. New York: Harcourt Brace Jovanovich. 
xxxix. Obasanjo, 0. (2003). Address presented at the inauguration of the technical committee on the review of the str ucture of local government councils, Abuja, June 25. Available at http://ww w.nigeriafirst.org/speeches.html.\{A ccessed 15 Sept., 2020\}.

xl. Odalonu, H. B. (2015). Challenges confronting local government administration in efficient and effective social service delivery: The Nigerian experience. International Journal of Public Administration and Management Research, 2 (5), 12-22.

xli. Odo, L. U. (2014). Local government and the challenges of grassroots development in Nigeria. Review of Public Administration and Management, 3 (6), 204-213.

xlii. Ogbette, A. S., Idam, M. O., \& Olumide, K. A. (2018). Local government administration and rural development in Enugu State, Nigeria (2007-2015). Journal of Public Administration and Governance, 8 (3), 185-210.

xliii. Okah, P. S., Iyiani, C. C., \& Aghedo, G. U. (2020). Perceived impacts of the National Poverty Eradication Programme (NAPEP) in poverty reduction and implications for social work practice. ESUT Journal of Social Sciences, 5 (1), 59-74.

xliv. Okah, P. S., Iyiani, C. C., Esin, E. E., \& Aghedo, G. U. (2020). Myth and realities of the occurrence of female early marriage among the people of Oron LGA of Akwa-Ibom State, Nigeria and the need for social work intervention. International Journal of Arts and Social Science, 3 (4), 259-271.

xlv. Ola, R. O. F. (2004). Local government theory \& practice: An examination of modernization efforts in three decades of Nigerian local government (1975-2003). In A. A. Agagu, \& R. O. F. Ola (Eds). Development agenda of Nigerian states. Ibadan: Flag Publisher.

xlvi. Olukotun, G. A. (2007). The role of local government areas in rural transport financing. Journal of Social sciences, 15 (92), 147-152.

xlvii. Otoghile, A. \& Edigin, L. U. (2011). Local Government Administration and Development: A survey of Oredo Local Government area of Edo State, Nigeria. African Research Review, 5 (3), 148-156.

xlviii. Oyedele, S. O., Osezua, E. M., Abdulkareem, A. K., \& Ishola, A. A. (2017). Local government administration and national development in Nigeria: Challenges and prospects. Ilorin Journal of Human Resource Management, 1 (1), 142-150.

xlix. Rondinelli, D. (1981). Government decentralization in comparative perspective: Theory and practice in developing countries. International Review of Administrative Sciences, 47 (2), 137-49.

1. Sehinde .B. (2008). Need for a review of statutory roles of local government for effective service. Journal of Contemporary Politics 1 (1), 102-115.

li. Shah, A. \& Sana, S. (2006). The new vision of local governance and the evolving role of local governments. In A. Shah (Ed). Local governance in developing countries. Washington, DC: World Bank.

lii. Sheafor, B. W. \& Horejsi, C. R. (2006). Techniques and guidelines for social work practice. Boston: Pearson.

liii. Smith, H., \& Revell, K. (2016). Micro-incentives and municipal behaviour: Political decentralization and fiscal federalism in Argentina and Mexico. World Development, 77, 231-248.

liv. Smoke, P. \& White, R. (2005). East Africa decentralizes. In World Bank (2005), East Asia decentralizes: Making local government work. World Bank, Washington, D.C.

lv. The 1976 Local Government Reforms Guidelines. Lagos: Federal Ministry of Information.

lvi. Tiku, O. T., Obetan, U. B., \& Onyenemerem, N. P. (2019). Local government autonomy and socio-economic development of rural areas in Nigeria. Global Journal of Applied, Management and Social Science, 16, $300-308$.

lvii. Tolu, L. \& Olagunjoye, A. (2010). Local government, corruption and democracy in Nigeria. Development in Africa, 12 (5), 227-235.

lviii. Uchechukwu, N., \& Obiora, O. C. (2016). Local government finance and rural development: A case study of Umuahia-North LGA, Abia State. Global Journal of Political Science and Administration, 4 (5), 32-38.

lix. Udoh, E. J. (2005). Demand and control of credit from informal services by rice producing women of AkwaIbom State, Nigeria. Journal of Agriculture and Social sciences, 1 (20, 152-155.

lx. Weingast, B. (1995). The economic role of political institutions: Market-preserving federalism and economic development. Journal of Law, Economics, and Organization 11 (1), 1-31.

lxi. Wiesner-Durán, E. (1992). Colombia. Descentralizacióny federalismo fiscal [Colombia. Decentralization and fiscal federalism]. Bogotá: Departamen to Nacional de Planeación.

lxii. Wunsch. J. (2001). Decentralization, local governance and recentralization in Africa. Public Administration and Development 21 (4) P.277.

Ixiii. Zakari ya 'u, I. (2014). Assessment of the impact of local government in Soba and Zaria local government areas, Kaduna State (2006-2011). M. Sc. Unpublished Thesis Submitted to Ahmadu Bello University, Zaria, Nigeria. 